\title{
THE HEAVY TRANSITION ELEMENTS
}


A Macmillan Chemistry Text

Consulting Editor: Dr Peter Sykes, University of Cambridge

COMPLEXES AND FIRST-ROW TRANSITION ELEMENTS: David Nicholls 


\title{
The Heavy Transition Elements
}

\author{
S. A. Cotton
}

School of Chemical Sciences

University of East Anglia

\section{F. A. Hart}

Department of Chemistry

Queen Mary College,

University of London 
ISBN 978-0-333-17090-8 ISBN 978-1-349-15591-0 (eBook)

DOI 10.1007/978-1-349-15591-0

(C) S. A. Cotton and F. A. Hart 1975

Reprint of the original edition 1975

All rights reserved. No part of this publication may be reproduced or transmitted, in any form or by any means, without permission.

First published 1975 by

THE MACMILLAN PRESS LT D

London and Basingstoke Associated companies in New York Dublin

Melbourne Johannesburg and Madras

SBN 333186656 (hard cover)

333170903 (paper cover)

Library of Congress Catalog Card No. 75-4950

This book is sold subject to the standard conditions of the Net Book Agreement

The paperback edition of this book is sold subject to the condition that it shall not, by way of trade or otherwise, be lent, resold, hired out, or otherwise circulated without the publisher's prior consent, in any form of binding or cover other than that in which it is published and without a similar condition including this condition being imposed on the subsequent purchaser. 


\section{Contents}

Preface $\quad$ xi

Abbreviations for Common Ligands xii

1 Zirconium and Hafnium 3

1.1 The Metals and their Aqueous Chemistry 3

1.2 Oxides 5

$\begin{array}{ll}1.3 \text { Halides } & 6\end{array}$

1.4 Other Binary Compounds 7

1.5 Complexes of Zirconium and Hafnium 7

$\begin{array}{ll}\text { 1.5.1 Complex halides } & 7\end{array}$

1.5.2 Adducts of the halides with uncharged ligands 8

1.5.3 Acetylacetonates and related compounds 9

$\begin{array}{lr}1.6 \text { Alkoxides and Dialkylamides } & 10\end{array}$

$\begin{array}{ll}1.7 \text { The Borohydrides } & 11\end{array}$

1.8 Compounds Involving Metal-Carbon Bonds 11

2 Niobium and Tantalum 15

2.1 The Metals, their Occurrence and Extraction 15

$\begin{array}{lr}2.2 \text { Oxides } & 16\end{array}$

$\begin{array}{ll}2.3 \text { Halides } & 17\end{array}$

2.3.1 The lower halides of niobium and tantalum 19

$\begin{array}{ll}\text { 2.3.2 Oxohalides } & 22\end{array}$

2.4 Other Simple Binary Compounds $\quad 22$

2.5 Alkoxides and Dialkylamides 23

2.6 Complexes of Niobium and Tantalum 23

$\begin{array}{ll}2.7 \text { Organometallics } & 24\end{array}$

3 Molybdenum and Tungsten $\quad 27$

$\begin{array}{ll}3.1 \text { Oxides } & 27\end{array}$

3.2 Oxy-anions 28

$\begin{array}{ll}3.2 .1 \text { Tungsten bronzes } & 29\end{array}$

$\begin{array}{ll}3.2 .2 & \text { Other binary compounds } \\ \end{array}$ 
$\begin{array}{ll}3.3 \text { Halides } & 30\end{array}$

$\begin{array}{lll}3.3 .1 & \text { Lower halides } & 31\end{array}$

$\begin{array}{ll}\text { 3.3.2 Polynuclear halide complexes } & 32\end{array}$

3.4 Oxohalides and Complex Oxohalides 33

$\begin{array}{ll}3.5 \text { Complexes of Molybdenum } & 34\end{array}$

3.5.1 Oxidation state VI 34

$\begin{array}{ll}3.5 .2 \text { Oxidation state V } & 35\end{array}$

$\begin{array}{ll}3.5 .3 \text { Oxidation state IV } & 37\end{array}$

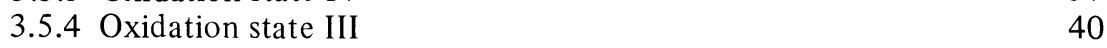

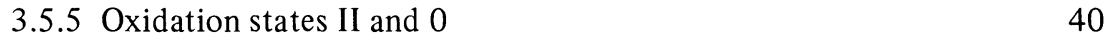

$\begin{array}{ll}3.6 \text { Organo-compounds } & 41\end{array}$

4 Technetium and Rhenium 43

4.1 The Metals and their Aqueous Chemistry 43

$\begin{array}{ll}4.2 \text { Halides } & 44\end{array}$

$\begin{array}{ll}4.3 \text { Oxides } & 45\end{array}$

$\begin{array}{ll}4.4 \text { Oxohalides } & 46\end{array}$

4.5 Perrhenates and Pertechnetates 47

4.6 Complexes of Technetium 47

4.7 Complexes of Rhenium 48

4.7.1 Rhenium (VII) 48

$\begin{array}{lll}4.7 .2 & \text { Rhenium (VI) } & 49\end{array}$

4.7.3 Rhenium (V) $\quad 50$

$\begin{array}{ll}\text { 4.7.4 Rhenium (IV) } & 53\end{array}$

4.7.5 Rhenium (III) $\quad 53$

4.7.6 Rhenium (II) $\quad 56$

4.7.7 Dinitrogen complexes of rhenium (I) 56

$\begin{array}{ll}\text { 4.7.8 Phosphine hydride complexes } & 57\end{array}$

5 Ruthenium and Osmium 59

$\begin{array}{ll}5.1 \text { Aqueous Cationic Chemistry } & 60\end{array}$

$\begin{array}{ll}5.2 \text { Halides } & 60\end{array}$

$\begin{array}{lll}\text { 5.2.1 Halide complexes } & 61\end{array}$

$\begin{array}{ll}5.2 .2 & \text { Other polynuclear systems } \\ 5.2 .3 & 62\end{array}$

$\begin{array}{ll}\text { 5.2.3 Other halide complexes } & 63\end{array}$

$\begin{array}{ll}\text { 5.2.4 Lower halides } & 63\end{array}$

$\begin{array}{ll}5.3 \text { Oxides and Oxo-anions } & 64\end{array}$

5.4 Nitrido Complexes of Osmium $\quad 65$

5.5 Complexes of Ruthenium $\quad 66$

5.5.1 Ammine complexes 66

$\begin{array}{ll}\text { 5.5.2 Nitrosyl and nitrogen complexes } & 67\end{array}$

$\begin{array}{ll}\text { 5.5.3 Sulphur dioxide complexes } & 70\end{array}$

$\begin{array}{ll}\text { 5.5.4 Carboxylates } & 71\end{array}$

5.5.5 Complexes with oxygen- and sulphur-containing ligands 72

$\begin{array}{ll}5.5 .6 \text { Complexes with } \pi \text {-bonding ligands } & 72\end{array}$

$\begin{array}{ll}5.6 \text { Complexes of Osmium } & 76\end{array}$

$\begin{array}{ll}\text { 5.6.1 Complexes with } \pi \text {-bonding ligands } & 76\end{array}$ 
$\begin{array}{ll}\text { 5.6.2 Hydrido and related complexes } & 77\end{array}$

$\begin{array}{ll}\text { 5.6.3 Carbonyl complexes } & 78\end{array}$

6 Rhodium and Iridium 81

6.1 The Metals and their Aqueous Chemistry 81

$\begin{array}{ll}6.2 \text { Halides } & 82\end{array}$

6.3 Oxides $\quad 83$

6.4 Some Other Binary Compounds 83

$\begin{array}{ll}6.5 \text { Complexes of Rhodium } & 83\end{array}$

$\begin{array}{lr}\text { 6.5.1 Rhodium (IV) } & 83 \\ 6.5 .2 & 83\end{array}$

\begin{tabular}{lr} 
6.5.2 & Rhodium (III) \\
\hline 6.5 .3 & 83
\end{tabular}

$\begin{array}{ll}\text { 6.5.3 Rhodium (II) } & 87\end{array}$

$\begin{array}{ll}\text { 6.5.4 Rhodium (I) } & 88\end{array}$

\begin{tabular}{lr} 
6.5.5 Rhodium (0) & 93 \\
\hline
\end{tabular}

6.6 Complexes of Iridium 94

$\begin{array}{ll}\text { 6.6.1 Iridium (IV) } & 94\end{array}$

$\begin{array}{ll}6.6 .2 \text { Iridium (III) } & 94\end{array}$

$\begin{array}{ll}6.6 .3 \text { Iridium (II) } & 98\end{array}$

6.6.4 Iridium (I) 99

7 Palladium and Platinum 107

$\begin{array}{ll}7.1 \text { The Metals and their Aqueous Chemistry } & 107\end{array}$

$\begin{array}{ll}7.2 \text { Halides } & 108\end{array}$

$\begin{array}{ll}7.3 \text { Oxides } & 110 \\ 7.4 \text { Some Other Binary Compounds } & 111\end{array}$

$\begin{array}{ll}7.4 \text { Some Other Binary Compounds } & 111\end{array}$

$\begin{array}{ll}7.5 \text { Complexes of Palladium and Platinum } & 111\end{array}$

$\begin{array}{ll}\text { 7.5.1 Palladium (0) and platinum (0) } & 111\end{array}$

$\begin{array}{ll}\text { 7.5.2 Palladium (I) and Platinum (I) } & 116\end{array}$

$\begin{array}{ll}\text { 7.5.3 Palladium (II) and platinum (II) } & 117\end{array}$

$\begin{array}{ll}\text { 7.5.4 Palladium (III) and platinum (III) } & 129\end{array}$

$\begin{array}{ll}\text { 7.5.5 Palladium (IV) and platinum (IV) } & 130\end{array}$

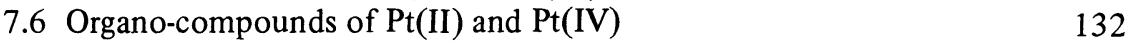

$\begin{array}{ll}7.7 \text { Recent Applications } & 134\end{array}$

8 Silver and Gold 137

8.1 The Metals, their Occurrence and Extraction 138

$\begin{array}{ll}8.2 \text { Hydrated Ions } & 138\end{array}$

$\begin{array}{ll}8.3 \text { Oxides } & 138\end{array}$

$\begin{array}{ll}8.4 \text { Halides } & 139\end{array}$

8.5 Other Compounds of $\mathrm{Ag}(\mathrm{I})$ and $\mathrm{Au}(\mathrm{I})$ and their Complexes 140

$\begin{array}{ll}\text { 8.6 Complexes of Silver (II) } & 145\end{array}$

$\begin{array}{ll}8.7 \text { Complexes of Gold (II) } & 147\end{array}$

$\begin{array}{ll}8.8 \text { Complexes of Silver (III) } & 147\end{array}$

$\begin{array}{ll}8.9 \text { Complexes of Gold (III) } & 148\end{array}$

$\begin{array}{ll}8.10 \text { Gold (III) Organo-compounds } & 149\end{array}$

8.11 Gold (V) 153 
9 Metal Complexes Containing $\pi$-Bonding Ligands 154

9.1 Bonding in an Octahedral Metal Carbonyl 154

$\begin{array}{ll}\text { 9.2 Discussion of the Molecular-orbital Diagram } & 160\end{array}$

9.2.1 The eighteen-electron (E.A.N.) rule 161

9.3 The Bonding in an Octahedral Complex (Using Group Theory) 161

$\begin{array}{ll}9.4 \text { General Considerations } & 162\end{array}$

$\begin{array}{ll}\text { 9.5 The Binary Carbonyls and their Derivatives } & 163\end{array}$

$\begin{array}{ll}\text { 9.5.1 Reactions of the metal carbonyls } & 164\end{array}$

$\begin{array}{ll}\text { 9.5.2 Substitution reactions } & 164\end{array}$

$\begin{array}{ll}\text { 9.5.3 Formation of anions and hydrides } & 167\end{array}$

$\begin{array}{ll}\text { 9.5.4 Heteronuclear carbonyls } & 171\end{array}$

$\begin{array}{ll}\text { 9.5.5 Oxidation reactions } & 171\end{array}$

$\begin{array}{ll}\text { 9.6 Metal Cyclopentadienyl and Arene Systems } & 172\end{array}$

$\begin{array}{ll}\text { 9.6.1 Bonding in ferrocene } & 173\end{array}$

$\begin{array}{ll}\text { 9.6.2 Hydrides and other derivatives } & 174\end{array}$

$\begin{array}{ll}\text { 9.7 Other Transition-metal } \pi \text { Complexes } & 177\end{array}$

$\begin{array}{ll}\text { 9.7.1 Transition-metal carborane complexes } & 177\end{array}$

$\begin{array}{ll}\text { 9.7.2 } \pi \text {-Allyl complexes } & 179\end{array}$

$\begin{array}{lr}\text { 9.7.3 Cyclobutadiene complexes } & 180\end{array}$

$\begin{array}{lr}\text { 9.7.4 Arene complexes } & 180\end{array}$

$\begin{array}{ll}\text { 9.7.5 Tropylium complexes } & 181\end{array}$

$\begin{array}{ll}\text { 9.7.6 Cyclo-octatetraene complexes } & 182\end{array}$

$\begin{array}{ll}\text { 9.8 Transition-metal Alkyls and Aryls } & 183\end{array}$

$\begin{array}{ll}\text { 9.9 The Binary Carbonyls. Synthesis and Structure } & 184\end{array}$

$\begin{array}{ll}\text { 9.9.1 The } \mathrm{d}^{5} \text { metals } & 184\end{array}$

$\begin{array}{ll}\text { 9.9.2 } \text { The }^{6} \text { metals } & 184\end{array}$

$\begin{array}{ll}\text { 9.9.3 } \text { The }^{7} \text { metals } & 184\end{array}$

$\begin{array}{ll}\text { 9.9.4 The } \mathrm{d}^{8} \text { metals } & 185\end{array}$

$\begin{array}{ll}\text { 9.9.5 The } \mathrm{d}^{9} \text { metals } & 185\end{array}$

$\begin{array}{ll}\text { 9.9.6 The } \mathrm{d}^{10} \text { metals } & 186\end{array}$

10 The Lanthanides 188

$\begin{array}{ll}10.1 \text { Introduction } & 188\end{array}$

$\begin{array}{ll}10.2 \text { The Metals } & 191\end{array}$

10.3 Simple Compounds of Rare-earth Metals 192

$\begin{array}{ll}\text { 10.3.1 Introduction } & 192\end{array}$

10.3.2 Compounds with elements of Groups I-IV 194

$\begin{array}{ll}\text { 10.3.3 The oxides } & 195\end{array}$

$\begin{array}{ll}\text { 10.3.4 Sulphides, selenides and tellurides } & 196\end{array}$

$\begin{array}{ll}\text { 10.3.5 The hydroxides } & 197\end{array}$

$\begin{array}{ll}\text { 10.3.6 Fluorides } & 197\end{array}$

10.3.7 The chlorides, bromides and iodides 198

$\begin{array}{ll}10.3 .8 \text { Lower halides } & 198\end{array}$

$\begin{array}{ll}\text { 10.3.9 Tetrafluorides } & 199\end{array}$

10.4 Electronic Spectra and Magnetic Properties of the Lanthanides 199

10.4.1 Absorption and fluorescence spectra 201

10.4.2 Magnetic properties 
10.5 Co-ordination Compounds of the Lanthanides 205

10.5.1 The available oxidation states 205

$\begin{array}{ll}\text { 10.5.2 The principal ligands } & 206\end{array}$

10.5.3 Co-ordination number and co-ordination polyhedra 207

10.5.4 Complexes of oxygen-based ligands 207

10.5.5 Complexes of nitrogen-based ligands 211

$\begin{array}{ll}\text { 10.5.6 Halide complexes } & 212\end{array}$

10.5.7 Compounds containing carbon-based ligands 212

$\begin{array}{ll}10.5 .8 \text { Other ligand atoms } & 214\end{array}$

10.5.9 Cerium (IV) complexes 214

10.6 Stability Constants of Lanthanide Ions in Water Solution 215

10.7 Lanthanide Complexes as N.M.R. Shift Reagents 217

11 The Actinides 220

$\begin{array}{ll}11.1 \text { Electronic Structures and Oxidation States } & 220\end{array}$

$\begin{array}{ll}\text { 11.2 Availability of the Actinides } & 222\end{array}$

$\begin{array}{ll}\text { 11.2.1 Actinium } & 222\end{array}$

$\begin{array}{ll}11.2 .2 \text { Thorium } & 223\end{array}$

$\begin{array}{ll}11.2 .3 \text { Protactinium } & 223\end{array}$

$\begin{array}{ll}11.2 .4 \text { Uranium } & 223\end{array}$

$\begin{array}{ll}\text { 11.2.5 Neptunium and plutonium } & 224\end{array}$

11.2.6 Americium, curium, berkelium, californium, einsteinium. 225

$\begin{array}{ll}\text { 11.2.7 Mendelevium, nobelium and lawrencium } & 226\end{array}$

11.3 Chemical and Structural Properties of the Actinide Series 226

$\begin{array}{ll}\text { 11.3.1 The tripositive actinide halides } & 227\end{array}$

$\begin{array}{ll}11.4 \text { Electronic Spectra of the Actinides } & 232\end{array}$

$\begin{array}{ll}11.5 \text { Actinium } & 235 \\ 11.6 \text { Thorium } & 235\end{array}$

$\begin{array}{ll}11.6 \text { Thorium } & 235 \\ 11.6 .1 \text { Haldes and halide complexes } & 236\end{array}$

11.6.1 Halides and halide complexes $\quad 236$

$\begin{array}{ll}\text { 11.6.2 Other complexes } & 237\end{array}$

$\begin{array}{ll}\text { 11.6.3 Lower-valent thorium compounds } & 238\end{array}$

$\begin{array}{ll}11.7 \text { Protactinium } & 238\end{array}$

$\begin{array}{ll}\text { 11.7.1 Halides and oxohalides } & 238\end{array}$

$\begin{array}{ll}\text { 11.7.2 Halide complexes } & 240\end{array}$

$\begin{array}{ll}\text { 11.7.3 Complexes with uncharged ligands } & 241\end{array}$

$\begin{array}{ll}\text { 11.7.4 Solution chemistry and oxy-salts } & 241\end{array}$

$\begin{array}{ll}11.8 \text { Uranium } & 241 \\ 111.8 .1 & 242\end{array}$

$\begin{array}{ll}11.8 .1 \text { Uranium (VI) } & 242\end{array}$

$\begin{array}{ll}\text { 11.8.2 Uranium (V) } & 246\end{array}$

$\begin{array}{ll}11.8 .3 \text { Uranium (IV) } & 248\end{array}$

$\begin{array}{ll}11.8 .4 \text { Uranium (III) } & 249\end{array}$

$\begin{array}{ll}11.9 \text { Neptunium, Plutonium and Americium } & 250\end{array}$

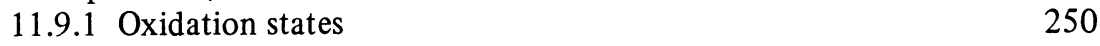

$\begin{array}{ll}11.9 .2 \text { Oxides } & 252\end{array}$

$\begin{array}{ll}\text { 11.9.3 Halides } & 253\end{array}$

11.9.4 Complex halides and oxohalides $\quad 254$

11.9.5 Other complexes of neptunium, plutonium and americium 255 
11.10 Curium and the Succeeding Actinides

11.10.1 Solid compounds

11.10.2 Berkelium tetrafluoride

11.10.3 Dicaesium hexachloroberkelate (IV)

11.10.4 Solution studies

11.11 Organo-compounds of the Actinides 258

11.12 The Post-actinide Elements

11.12.1 Element 104 


\section{Preface}

The study of transition metals and their compounds occupies a prominent place in most first-degree chemistry courses. In many cases considerable attention is paid to the first-row transition series, much less attention to the second- and third-row metals, while the lanthanides and actinides are treated with the utmost brevity. The origin of this imbalance is probably to be found in a combination of two factors. The first is that the industrially important, well-known and abundant transition metals are the $3 \mathrm{~d}$ metals such as copper, iron and nickel. Secondly, the quantitative aspects of ligand-field theory are more readily applied to the $3 \mathrm{~d}$ metals than to the $4 \mathrm{~d}, 5 \mathrm{~d}, 4 \mathrm{f}$ and $5 \mathrm{f}$ metals because of the relative magnitudes of the physical parameters, such as the spin-orbit coupling constant and the crystal-field splitting parameter, that are involved.

This book, which is a sequel to a cognate volume ${ }^{\dagger}$ dealing with the $3 \mathrm{~d}$ metals, gives an account of the $4 \mathrm{~d}, 5 \mathrm{~d}, 4 \mathrm{f}$ and $5 \mathrm{f}$ metals, which it is hoped will be adequate for any first-degree requirements and for postgraduate courses dealing with general aspects of transition-metal chemistry. The treatment is given in sufficient range and detail to allow considerable latitude to the course organiser and student in their choice of precise topic and level of approach. We have not hesitated to include a high proportion of descriptive chemistry, in the conviction that a sound knowledge of experimental facts forms the basis of any scientific discipline. This style of treatment may also be useful to research workers requiring a general view of some particular area of $4 \mathrm{~d}, 5 \mathrm{~d}, 4 \mathrm{f}$ and $5 \mathrm{f}$ chemistry; it is not intended, however, to provide a detailed introduction to research.

We would like to thank a number of our colleagues, particularly Professor D. C. Bradley, Dr D. M. P, Mingos and Dr P. Thornton for reading portions of the manuscript and making constructive comments. Any remaining errors are our own responsibility. We also wish to thank Mrs H. Matthewman and Mrs T. Gue for their very efficient typing of the manuscript. Finally, we both wish to thank Mrs Eileen Hart for preliminary typing and for much assistance and encouragement.

\section{S. A. Cotton F. A. Hart}




\section{Abbreviations for Common Ligands}

$\begin{array}{ll}\text { acac } & \text { acetylacetone anion } \\ \text { bipy } & 2,2^{\prime} \text {-bipyridyl } \\ \text { bzac } & \text { benzoylacetone anion } \\ \text { cp } & \text { cyclopentadienyl anion } \\ \text { diars } & o \text {-phenylenebisdimethylarsine } \\ \text { diglyme } & 2,2^{\prime} \text {-dimethoxydiethylether } \\ \text { diphos } & 1,2 \text {-diphenylphosphinoethane } \\ \text { dma } & \text { N,N-dimethylacetamide } \\ \text { dtpa } & \text { diethylenetriaminepenta-acetic acid anion } \\ \text { EDTA } & \text { ethylenediaminetetra-acetic acid anion } \\ \text { hal } & \text { halogen anion } \\ \text { hfac } & \text { hexafluoroacetylacetone anion } \\ \text { nta } & \text { nitrilotriacetic acid anion } \\ \text { oxine } & \text { 8-hydroxyquinoline anion } \\ \text { phen } & 1,10 \text {-phenanthroline } \\ \text { py } & \text { pyridine } \\ \text { THF } & \text { tetrahydrofuran }\end{array}$




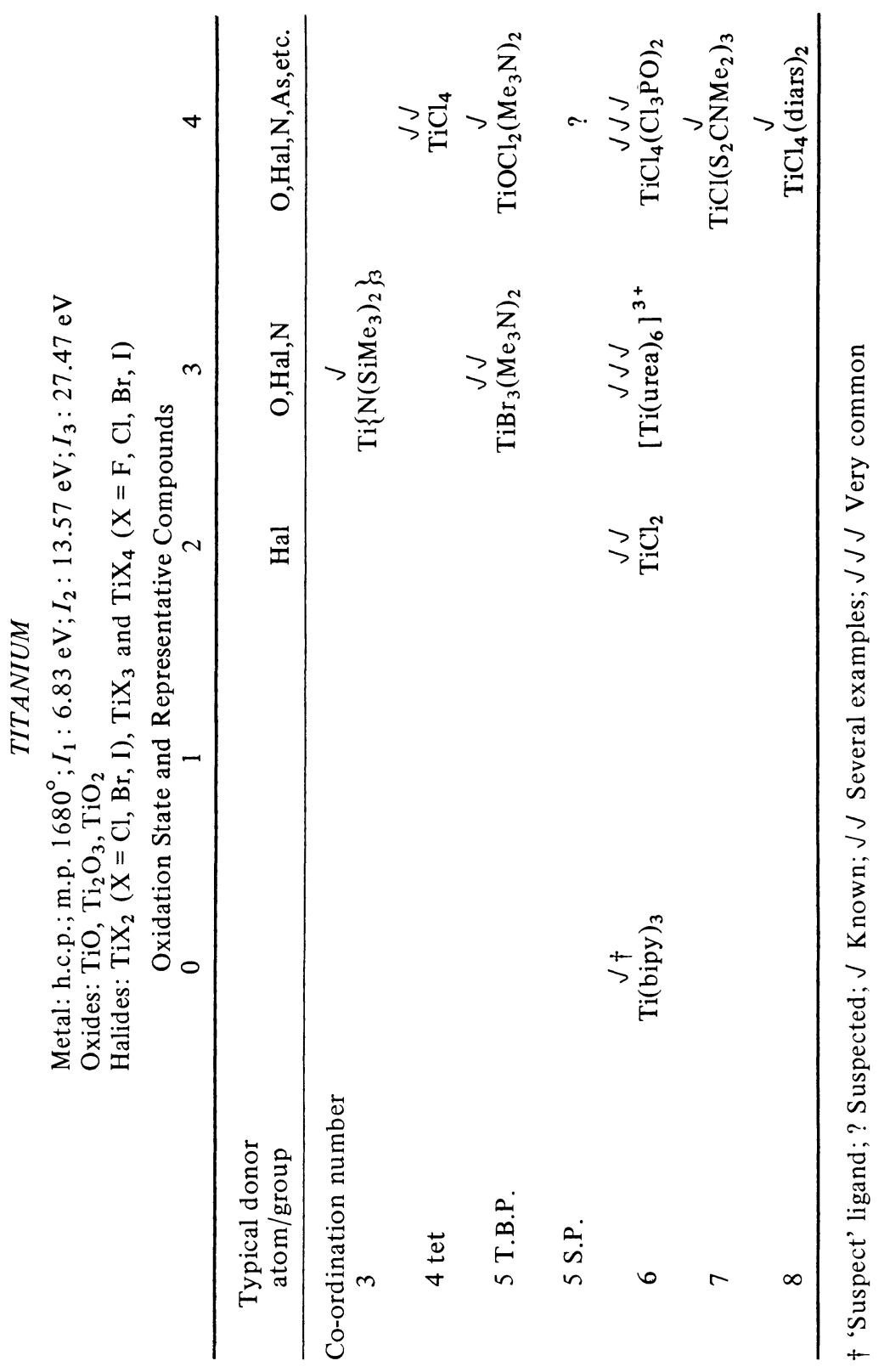

